\title{
Comparison of Three Methods for Detection of Plasmodium Oocysts an Wild-Caught Mosquitoes
}

\author{
D. EDOH ${ }^{1}$ AND H. HAJI ${ }^{2}$ \\ ${ }^{1}$ Swiss Tropical Institute, Socinstrasse 57, Postfach, 4002 Basel, Switzerland; \\ ${ }^{2}$ Ifakara Centre, Box 53, Ifakara, Tanzania
}

(Accepted 29 April 1998)

\begin{abstract}
One hundred forty-nine Anopheles gambiae s.l. and 260 A. funestus were collected from the field in Namawala, Tanzania in June 1994. The mosquitoes were dissected and examined for plasmodium oocysts using two microscopic techniques and the polymerase chain reaction (PCR) method. The oldest and simplest technique, the saline test, detected oocysts in 94 out of the 97 mosquitoes found to have oocysts by the more sensitive merbromin stain and PCR techniques. The saline test was found to be a sensitive and reliable field technique for detection of large Plasmodium oocysts in mosquitoes. The merbromin staining technique was as sensitive as PCR, detecting even small oocysts.
\end{abstract}

Key Words: Plasmodium oocysts, mosquitoes, PCR, microscopic techniques, A. gambiae, A. funestus

Résumé-Cent quarante-neuf Anopheles gambiae s.l. et deux cent soixante (260) A. funestus ont été collectées en juin 1994, dans un champ à Namawala en Tanzanie. Les moustiques étaient disséqués et examinés pour la détection des oocysts de Plasmodium par deux techniques microscopiques et par la méthode de réaction de la chaîne polymérase (RCP). L'emploi de la solution saline, une technique très ancienne et très simple, a permis de détecter des oocytes chez 94 des 97 moustiques ayant déjà témoigne de la présence des oocysts par les techniques très sensibles: les traces de merbromine et la RCP. Le test par la solution saline s'est révélé être une technique sensible et faible de terrain pour détecter de gros oocytes chez les moustiques infectés de Plasmodium. La technique des traces de merbromine était aussi sensible que la RCP détectant même les petits oocytes.

Mots Clés: oocysts de Plasmodium, moustiques, RCP, techiques microscopiques, A. gambiae, A. funestus

\section{INTRODUCTION}

T The saline test is perhaps the oldest technique for the detection of oocysts (see Burkot et al., 1984), and involves simply dissecting the mosquitoes in physiological saline solution under an ordinary dissecting microscope providing 200x magnification. Trained eyes can

Corresponding author: DE.

Present address: Zoology Dept, University of Ghana, Box 67, Legon, Accra, Ghana.

E-mail: Edoh@ug.edu.gh easily recognise the oocysts as spherical bodies in the periphery of the gut, as the gut is pulled and stretched out during dissection. The technique requires care in establishing the proper setting of the incident light from the microscope to the gut, and is limited by the size of the oocysts.

Merbromin is a mercurochrome preparation. A $1 \%$ solution in distilled water is used for the detection of oocysts (Githeko et al., 1992; Smith et al., 1993; Vaughan et al., 1994). The mosquito gut, dissected in saline or distilled water, is transferred to a drop of merbromin solution on a microscope 
slide, covered with a cover slip and examined using a compound microscope (total magnification 200 or $400 x)$. The advantage of this technique is that the oocysts are well stained, with dark coloration, which makes it easy to see the characteristic features of malaria parasites. Experienced/or well trained workers can detect oocysts as early as two days after an infectious bloodmeal.

The PCR technique is by far the most complicated and expensive of the three techniques (Baker et al., 1994; Edoh, 1995). However, because the target DNA molecules can be amplified severalfold, even tiny oocysts can be detected. PCR, however, has to be carried out under sterile conditions to avoid contamination with unwanted DNA molecules. Sterility is required even during mosquito dissection. Futhermore, it may be necessary to optimise the PCR reaction conditions in order to obtain reproducible results.

In the course of experiments to determine the infectiousness of Plasmodium falciparum gametocytes for Anopheles gambiae s.l. and A. funestus and to assess the genetic heterogeneity of oocysts of malaria parasites found in these vectors, an opportunity arose to compare the sensitivity of above three methods for the detection of oocysts in mosquito midguts.

\section{Materials And Methods}

The procedure for assessing the performance of the tests on vector mosquitoes was as follows:

For the saline test, mosquitoes were dissected in a $0.9 \% \mathrm{NaCl}$ physiological saline using a dissecting microscope and the guts were examined for oocysts. During dissection, fresh sterileneedles were used for each mosquito to prevent cross contamination. For the merbromin test, all the guts that had already been dissected out for the first test, regardless of whether they had been negative or positive, were stained in $1 \%$ merbromin solution and re-examined under a microscope. Since PCR was to be carried out, the dissection and staining were performed carefully to avoid crosscontamination.

For the PCR test, all the mosquito guts previously examined, whether they had been found negative or positive by the first two techniques, were processed to extract DNA, which was then amplified for the detection of merozoite surface protein, MSP 1, of the major malaria parasite, $P$. falciparum. The midguts were first digested in lysis buffer containing proteinase $\mathrm{K}$ at $55^{\circ} \mathrm{C}$ for 1 hour, phenol/chloroform purified and the parasite DNA pelleted with isopropanol (Ranford-Cartwright et al., 1991). The parasite DNA, stored at $-20^{\circ} \mathrm{C}$, was amplified using PCR primers recognising tandemly repeated amino acid sequences in Block 2 of MSP-1; first with outer primers 01 and 02 (of sequences $5^{\prime}$ to $3^{\prime}$ 'CACATGAAAGTTATCAAGAACTTGTC' and 'GTACGTCTAATTCATTTGCACG'), then with nested primers $\mathrm{N} 1$ and N2 (of sequences $5^{\prime}$ to $3^{\prime}$ 'GCAGTATTGACAGGTTATGG' and 'GATTGAAAGGTATTTGAC') (Babiker et al., 1994). Amplification was performed at $94^{\circ} \mathrm{C}$ for 25 $\mathrm{s} ; 50^{\circ} \mathrm{C}$ for $35 \mathrm{~s} ; 68^{\circ} \mathrm{C}$ for $150 \mathrm{~s}$; for 30 cycles (Ranford-Cartwright et al., 1991).

To establish their specificity and sensitivity, the three methods were first tested on 20 laboratory-reared mosquitoes obtained from La Roche Ltd., Basel. Ten mosquitoes were uninfected and 10 had been infected with $P$. falciparum gametocyte-enriched cultures through membrane feeding. The study was designed such that none of the examiners using one of the three tests knew the other two's findings. All 10 uninfected mosquitoes were found negative for oocysts by saline, merbromin and PCR. The 10 infected mosquitoes were found to contain oocysts by each of the three methods. This result indicates that all three tests were highly specific for oocyst detection in laboratory-reared mosquitoes.

Field experiments were carried out in the village of Namawala, near Ifakara in southern Tanzania. Mosquitoes which had fed during the night were collected in the morning by resting collections from inside houses. A total of 409 mosquitoes were collected of which $149(36 \%)$ were $A$. gambiae s.l. and $260(64 \%)$ were $A$. funestus. The mosquitoes were placed in paper cups covered with nets, and kept for seven days in an insectary to allow oocysts to develop then dissected. The mosquito midguts were examined for oocysts using the three methods. For each method, the examination was carried out by a different trained worker. The study design was such that neither of the examiners using the saline, merbromin and PCR tests knew the other's findings.

\section{Results ANd Discussion}

In the preliminary survey on 20 laboratory-bred mosquitoes, all three assays showed $100 \%$ specificity. Of the 97 infected wild-caught mosquitoes, the saline test detected oocysts in 94 of them. The merbromin and PCR test detected 
Table 1. Numbers of mosquitoes with and without oocysts identified by three different methods namely phosphate buffered saline microscopy (saline test), merbromine stain microscopy (merbromin test) and polymerase chain reaction (PCR)

\begin{tabular}{lrcr}
\hline & \multicolumn{3}{c}{ Methods } \\
\cline { 2 - 4 } Results & Saline & Merbromin & PCR \\
\hline Positives & & & \\
$\quad$ A. gambiae s.l. & 34 & 35 & 35 \\
$\quad$ A. funestus & 60 & 62 & 62 \\
Negatives & & & \\
$\quad$ A. gambiae s.l. & 115 & 114 & 114 \\
$\quad$ A. funestus & 200 & 198 & 198 \\
\hline Total & 409 & 409 & 409 \\
\hline
\end{tabular}

oocysts in all 97 . Thus, the simplest of the three diagnostic tests-the saline test-missed only three positive guts each of which had one small oocyst. The sensitivity of the saline test was therefore $97 \%$ that of PCR or merbromin tests.

The frequency distribution of oocysts in the guts as obtained using the merbromin test is shown in Table 2. The number of oocysts per gut ranged from 1 to 7 . Most of the mosquitoes $(30 \%)$ had one oocyst per gut. The distribution of the number of oocysts per mosquito is skewed to the right, with a median of 0 , geometric mean of 3.14 and SD of 1.39; only 4 mosquitoes had 7 oocysts each.

Recent development of advanced 'high-tech' methods has increased the potential for detecting different stages of the life cycle of tropical disease parasites, in both humans and vectors. Both radioactive and non-radioactive PCR and hybridisation techniques have been developed and some are already undergoing field trials (Rodgers et al., 1990; Snounou et al., 1993) for use in tropical diseases research. Other techniques also in use or being developed include enzymelinked immunosorbent assay (ELISA) and immunoflorescence assay (IFA) (Zavala et al., 1982; Githeko et al., 1992; Zimmerman et al., 1992; Tassanakajon et al., 1993). These methods are specific, accurate and fast and although appear likely to replace the old ones, this study suggests otherwise.

In the past, the saline test with or without staining was the standard method used for the detection of plasmodium oocysts in mosquitoes (Burkot et al., 1984).

A major disadvantage of the saline microscopic method is that it does not distinguish the species of oocysts and therefore it cannot be used to
Table 2. Frequency distribution of oocysts in midguts of mosquitoes dissected and examined by merbromin test

\begin{tabular}{lcc}
\hline & \multicolumn{2}{c}{ Frequency } \\
\cline { 2 - 3 } $\begin{array}{l}\text { No. of } \\
\text { oocysts }\end{array}$ & \multicolumn{2}{c}{} \\
per gut & A.gambine s.l. & A. funestus \\
\hline 1 & 14 & 198 \\
1 & 10 & 22 \\
2 & 9 & 18 \\
3 & 3 & 11 \\
4 & 4 & 4 \\
5 & 3 & 4 \\
6 & 3 & 2 \\
7 & 3 & 1 \\
\hline Total & 149 & 260 \\
\hline
\end{tabular}

quantify $P$. falciparum infection in situations where other Plasmodium species are present. In contrast, the PCR method used is specific for $P$. falciparum. In Namawala, sporozoite rates for different Plasmodium species in wild mosquitoes have not been determined. In human inhabitants, however, Smith et al. (1993) reported that $P$. falcipartum occurs perennially in $60-75 \%$ of the mosquitoes while $P$. malariae occurs seasonally in less than 10\% (Smith et al., 1993). Plasmodium malariae infections donot last as long as those of $P$. falciparum (Beier et al., 1994) and therefore even fewer than $10 \%$ P. malariae sporozoites are likely to be found in a sample of field-caught mosquitoes.

In the field, where epidemiological surveys in tropical parasitic disease research is done, large samples of infected mosquitoes are often collected (Baker, 1993; Kain and Lanar, 1991). How and where these samples are processed should depend on the information that is needed. To determine the presence of oocysts, microscopy, with or without staining, could be the method of choice. The distribution of oocysts can also be determined microscopically. Transportation of samples, which is often cumbersome and costly can thus be avoided.

There is, however, information that only modern techniques, such as PCR, can provide. For instance, PCR has been used to identify species and strains of Plasmodium in the vector and also species-specific malaria transmission (Snounou et al., 1993; Tirasophon et al., 1993). Furthermore, the PCR technique would probably be the method of choice in surveys over large areas involving large vector populations with high man-biting indexes as in Tanzania (Smith et al., 1993), since 
conventional microscopic methods would be timeconsuming and require many microscopes and trained personnel. In such cases, it is worth considering whether the PCR technique could be set up in the study area. It has been shown in Ifakara Centre in Tanzania that this is feasible.

This study was not designed for cost comparison of the techniques. However, some cost estimates were made. The cost of the saline test was a fifth of that of PCR. The expenditure for the saline test was due entirely to labour costs; microscopists were paid a daily allowance for dissecting and examining mosquito midguts. The PCR reagents were purchased at a discount from Pelker Elmer, Switzerland and airfreighted to Tanzania at a reduced rate, without which the costs would probably have been higher. The cost of the equipment and the highly qualified personnel needed for the PCR assay have not been considered here. Most developing countries cannot afford to pay for these 'high-tech' techniques owing to economic constraints. Therefore, techniques need to be identified that are inexpensive, practical, sensitive, easy to use and reasonably accurate. For now microscopic techniques appear to fit the bill.

Acknozledgment-We thank J. Jupitfer and his group for processing the samples, Derek Charlwood for advice, Helen Guyatt and Jennifer Jenkins for commenting on the manuscript. We also thank Professors M. Tanner and W. L. Kilama for their support. This research was funded by grants from the Friedrich Miescher-Institut, CibaGeigy Jubiläums Stiftung, the Swiss Directorate for Technical Cooperation and Humanitarian Aid (SDC), the Dutch government, and the WHO Immunology Research and Training Centre (IRTC) Geneva. Research clearance was granted by the Tanzanian Commission for Science and Technology (UTAFITI) as per ref NSR/RCA 90.

\section{REFERENCES}

Babiker H. A., Ranford-Cartwright L. C., Currie D., Charlwood J. D., Billingsley P., Teuscher T. and Walliker D. (1994) Random mating in a natural population of the malaria parasite Plasmodium falciparum. Parasitol. 109, 413-421.

Baker R. H. Jr (1993) Use of PCR in the field. Parasitol. Todoy 10, 117-119.

Baker R. H., Banchongaksorn T., Courval J. M., Suwonkerd W., Rimwungtragoon K., Srittong N. and Wirth D.F. (1994) DNA probes as epidemiologic tools for surveillance of Plasmodium falcipartum malaria in Thailand. Int. J. Epidemiol. 23, 161-168.

Beier J. C., Oster C. N., Onyango F. K., Bales J. D., Sherwood J. A., Perkins P. V., Chumo D. K., Koech D. V., Whitmire R. E., Roberts C. R. and Diggs C. R. (1994) Plasmodium falciparum incidence relative to entomological inoculation rates at a site proposed for testing malaria vaccines in western Kenya. Am. J. Trop. Med. Hyg. 50, 529-536.

Burkot T. R., Zavala F., Gwadz R. W., Collins F. W., Nussenzweig R. S. and Roberts D. R. (1984) Identification of malaria infected mosquitoes by a two-site enzyme-linked immunosorbent assay. Am. J. Trop. Med. Hyg. 33, 227-231.

Edoh D. (1995) Rejoinder: The use of PCR in the field. Parasitol. Today 11, 68.

Githeko A. K., Brandling-Bennett A. D., Beier M., Atieli F., Owaga M. and Collins F. W. (1992) The reservoir of Plasmodium falciparum in a holoendemic area of western Kenya. Trans. R. Soc. Trop. Med. Hyg. 86, 355-358.

Kain K. C. and Lanar D. E. (1991) Determination of genetic variation within Plasmodium falcipartum by using enzymatically amplified DNA from filter paper disks impregnated with whole blood. J. Clin. Microbiol. 26, 1171-1174.

Ranford-Cartwright L. C., Balfe P., Carter R. and Walliker D. (1991) Genetic hybrids of Plasmodium identified by amplification of genomic DNA from single oocysts. Mol. Biochem. Parasitol. 49, 239-244.

Ranford-Cartwright L. C., Balfe P., Carter R. and Walliker D. (1993) Frequency of cross-fertilization in the human malaria parasite Plasmodium falciparum. Parasitol. 107, 11-18.

Rodgers M. R., Popper S. J. and Wirth D. F. (1990) Amplification of kinetoplast DNA as a tool in the detection and diagnosis of Leishmania. Exp. Parasitol. $71,267-275$.

Smith T., Charlwood J. D., Kihonda J., Mwankuyse S., Billingsley P., Meuwissen J., Lyimo E., Takken W., Teuscher T. and Tanner T. (1993) Absence of seasonal variation in malaria parasitaemia in an area of intense seasonal transmission. Acta Tropica 54, 5557.

Snounou G., Pinheiro L., Goncalves L., Fonseca L., Dias F., Brown K. N. and doRosario V. E. (1993) The importance of sensitive detection of malaria parasites in the human and mosquito hosts in epidemiological studies, as shown by the analysis of field samples from Guinea Bissau. Trans. R. Soc Trop. Med. Hyg. 87, 649-653.

Tassanakajon A., Boonsaeng V., Wilairat P. and Panyim S. (1993) Polymerase chain reaction detection of Plasmodium falciparum in mosquitoes. Trans. $R$. Soc. Trop. Med. Hyg. 87, 273-275.

Tirasophon W., Tassanakajon A., Boonsaeng V., Panyim S. and Wilairat P. (1993) Sensitive detection of Plasmodium falcipartum in blood and mosquito by DNA amplification. Trans. R. Soc. Trop. Med. Hyg. $35,117-120$. 
Vaughan J., Noden B. H. and BeierJ.C. (1994)Sporogonic development of cultured Plasmoditm falciparim in six species of laboratory-reared Anopheles mosquitoes. Am. J. Trop. Med. Hyg. 51, 233-243.

Zavala F., Gwadz R. W., Collins F. H., Nussenzweig R. S. and Nussenzweig V. (1982) Monoclonal antibodies to circumsporozoite proteins identify the species of malaria parasite in infected mosquitoes. Nature 299 $737-738$.

Zimmerman P. A., Dadzie R. Y., De Sole G., Rema J., Soumbey E. and Unnasch T. R.(1992) Onchocerca volvulus DNA probes classification correlates with epidemiological patterns of blindness. I. Infoct. Discases $165,964-968$. 